\title{
Occurrence and isotype of antibodies against peripheral nerve myelin in serum from patients with peripheral neuropathy and healthy controls
}

\author{
MABEL CRUZ,* JAN ERNERUDH,† TOMAS OLSSON,* BO HÖJEBERG,* \\ HANS LINK* \\ From the Department of Neurology, Karolinska Institute, Huddinge University Hospital, Stockholm, ${ }^{*}$ and \\ Department of Neurology, Linköping University Hospital, Linköping, Sweden
}

SUMMARY Antibodies against peripheral nerve myelin have previously been demonstrated in serum from patients with peripheral neuropathy and IgM paraproteinaemia, and a causal relationship has been suggested. Using enzyme-linked immunosorbent assay (ELISA), anti-myelin antibodies were found in sera from eight of 16 patients with polyneuropathy and paraproteinaemia, but also in $17 \%$ of 109 patients with peripheral neuropathy lacking monoclonal immunoglobulin, including five of 10 patients with Charcot-Marie-Tooth disease, and in $16 \%$ of 142 blood donors. The antibodies were mostly of IgM class in the two neuropathy groups, while blood donors had mostly IgA antibodies, and a few subjects of each group had antimyelin antibodies of two different isotypes. Western blot confirmed the ELISA results in a majority of antibody positive sera and revealed a 25-30 kD myelin target antigen for sera from the three groups, and for some of the nonparaproteinaemic sera also a $100 \mathrm{kD}$ myelin target antigen. Our results demonstrate that the presence of serum autoantibodies against peripheral nerve myelin does not necessarily indicate a pathological event.

There is an association between polyneuropathy and monoclonal gammopathies. ${ }^{1} \mathrm{~A}$ causal relationship between IgM M-component in serum and polyneuropathy has been suggested. ${ }^{2}$ Recent reports of delayed appearance in serum of IgM M-component in a patient with polyneuropathy and antibody binding to peripheral nerve, ${ }^{3}$ and the presence of antibodies against myelin associated glycoprotein in a patient with polyneuropathy lacking M-component in serum ${ }^{4}$ have suggested that antibodies against myelin may also be of importance in polyneuropathy patients without demonstrable M-component in serum, and that it might be worth searching for such antibodies in any patient with polyneuropathy. However, in our opinion the significance of antibodies against peripheral nerve myelin (PNM) is not clear, since previous studies have included, as negative controls, pooled normal serum, serum IgM M-

\footnotetext{
Address for reprint requests: Dr Mabel Cruz, Department of Neurology, Huddinge University Hospital, S-141 86 Huddinge, Stockholm, Sweden.
}

Received 17 November 1987 and in revised form 10 February 1988. Accepted 16 February 1988 components from patients without polyneuropathy or samples from only a few healthy individuals. Thus, the extent to which such autoantibodies are found in healthy subjects is not known with certainty. Evidence of the presence of anti-myelin antibodies in serum from healthy subjects has in fact recently been presented. $^{5}$

We now report frequencies and isotypes of antibodies to PNM in sera from patients with peripheral neuropathy subgrouped according to the presence or absence of serum M-component and also in sera from blood donors. Our data indicate that such antibodies of IgM, IgA and/or IgG isotypes may occur in sera from patients with peripheral neuropathy of different aetiology and lacking M-protein as well as in healthy subjects, thereby casting doubts to the possible primary pathogenetic importance of such antibodies in neuropathy.

\section{Materials and methods}

Sera were obtained from 125 patients with peripheral neuropathy (table 1). Agarose electrophoresis or isoelectric focusing revealed monoclonal $\mathrm{M}$-component in 16 patients who all had polyneuropathy. The M-component was of IgM isotype in 11 patients and IgG in five. Of the remaining 
Table 1 Survey of patients with neuropathy and blood donors for reactivity in ELISA with peripheral nerve myelin

\begin{tabular}{|c|c|c|c|c|c|}
\hline \multirow[b]{2}{*}{ Diagnosis } & \multirow{2}{*}{$\begin{array}{l}\text { No of } \\
\text { patients }\end{array}$} & \multicolumn{4}{|c|}{ No with anti-peripheral nerve myelin reactivity } \\
\hline & & Total* & $\operatorname{Ig} M$ & $\operatorname{Ig} A$ & $\operatorname{Ig} G$ \\
\hline \multicolumn{6}{|l|}{ Polyneuropathy and $\mathrm{M}$-component } \\
\hline IgM isotype & 11 & 8 & 7 & 3 & 1 \\
\hline \multirow{2}{*}{\multicolumn{6}{|c|}{ Waldenström disease without neuropathy }} \\
\hline & & & & & \\
\hline and M-component of IgM isotype & 12 & 0 & 0 & 0 & 0 \\
\hline Neuropathy without $\mathbf{M}$-component & 109 & 19 & 13 & 4 & 6 \\
\hline Guillain-Barré syndrome & 14 & 2 & 1 & 1 & 1 \\
\hline Diabetes mellitus & 12 & 1 & 1 & 0 & 0 \\
\hline Charcot-Marie-Tooth disease & 10 & 5 & 4 & 0 & 1 \\
\hline Vitamin $_{12}$ deficiency & 3 & 2 & 1 & 1 & 1 \\
\hline Shoulder neuritis & 3 & 1 & 1 & 0 & 0 \\
\hline Lyme disease & 2 & 1 & 1 & 0 & 0 \\
\hline Paraneoplastic polyneuropathy & 2 & 1 & 1 & 0 & 0 \\
\hline Neuropathy of other known causes & 13 & 2 & 2 & 0 & 0 \\
\hline Neuropathy of unknown cause & 50 & 4 & i & 2 & 3 \\
\hline Blood donors & 142 & 23 & 11 & 16 & 11 \\
\hline
\end{tabular}

*Some subjects had antibodies of more than one isotype.

109 patients, 90 had polyneuropathy, 14 Guillain-Barré syndrome, three shoulder neuritis and two polyradiculitis secondary to Borrelia burgdorferi infection. Sera were also obtained from 12 patients with Waldenström's disease and monoclonal serum IgM but no signs or symptoms of polyneuropathy, and from 142 blood donors who all denied polyneuropathy symptoms in a detailed questionnaire. The age of the blood donors (56 females) was 20-62 years (mean 38). Clinically overt polyneuropathy was assumed to exist when two of the following signs were demonstrable: Distal bilateral sensory impairment, distal bilateral muscle weakness and wasting, bilateral decrease or loss of tendon reflexes. Possible effects of aging on these variables were considered. All polyneuropathy patients were thoroughly evaluated, including a battery of blood and urine tests, and in most cases also chest radiography, neurophysiological and cerebrospinal fluid analysis.

Bovine PNM was prepared from lumbosacral plexus. ${ }^{6}$ It has previously been shown that human anti-myelin antibodies react with myelin of human as well as bovine origin. $^{7-10}$

The ELISA used for detection of anti PNM antibodies has been described elsewhere. ${ }^{11}$ In brief, microtitre plates (Polyviril Chloride Microtitration plates, Virginia, USA) were coated with $0.1 \mathrm{ml} /$ well of bovine PNM $(80 \mu \mathrm{g} / \mathrm{ml})$ in $0.05 \mathrm{M}$ sodium carbonate buffer $\mathrm{pH} 9.6$ and incubated over-night at $4^{\circ} \mathrm{C}$. Thereafter, the plates were incubated with $100 \mu \mathrm{l}$ of phosphate buffered saline $\mathrm{pH} 7.2$ containing $0.05 \%$ Tween 20 and $5 \%$ of bovine serum albumin (BSA) for 2 hours at room temperature. Patient sera were incubated for 90 minutes at $37^{\circ} \mathrm{C}$ in the same buffer solution. Optimal discrimination between antibody positive and negative samples was seen at dilutions of sera to concentrations of $15 \mathrm{mg} / \mathrm{l}$ for IgM and $10 \mathrm{mg} / \mathrm{l}$ for IgG and IgA. After incubation of samples and washings, the wells were incubated with alkaline phosphatase conjugated high affinity purified rabbit anti-human IgG, IgM or IgA antiserum. Control samples, negative and positive for antibody were included on each plate and consisted of (A) pooled serum from 200 blood donors; (B) sera from patients with serum Mcomponent of IgG, IgA and IgM class, respectively, but without polyneuropathy; (C) sera from patients with poly- neuropathy and previously demonstrated IgG, IgA and IgM antibody activity against bovine PNM. Arbitrarily, antiPNM antibodies were considered to be present when absorbance exceeded that of pooled normal serum by 0.2 units.

For Western blot, PNM was separated by sodium dodecylsulphate polyacrylamide gel electrophoresis (SDSPAGE) and transferred electrophoretically to nitrocellulose membranes. ${ }^{1213}$ Electroblotting was performed in TransBlot Cell equipment (Bio Rad, Ca, USA) at a constant current of 0.1 A during 16 hours at $4^{\circ} \mathrm{C}$. Separation gels contained no proteins after this transfer as shown by Coomassie blue staining. The blots were cut into 4-5 mm strips and incubated for $2 \mathrm{~h}$ in $5 \%(\mathrm{w} / \mathrm{v})$ bovine serum albumin $/ 10 \mathrm{mM}$ Tris- $\mathrm{HCl} / 0.9 \% \mathrm{NaCl}, \mathrm{pH} 7 \cdot 6$, to avoid unspecific binding to the possible empty space on the nitrocellulose membrane and overnight at room temperature in patients' serum diluted 1:100. After several washings in Trissaline buffer, the blots were incubated in a 1:500 dilution of high affinity purified goat anti-human IgG, IgM or IgA antiserum. In order to increase sensitivity for antibody detection, secondary immunolabelling included an avidin-biotin peroxidase procedure. ${ }^{1415}$ Controls consisted of pooled blood donor serum and sera from patients with serum M-component but without polyneuropathy and no antibodies against PNM as documented by ELISA. Inspection of strips for antibody binding was performed without knowledge of identity of the patient sample.

\section{Results}

Antibodies against PNM were found by ELISA in serum from eight of 11 patients with polyneuropathy and IgM M-component, and in none of five with IgG M-component (table 1). The anti-PNM antibodies were restricted to the IgM isotype in five patients, while two had such antibodies both of $\operatorname{IgM}$ and $\operatorname{IgA}$ isotype. The remaining patient showed anti-PNM antibodies of both IgA and IgG isotype. Using Western blot, presence, specificity and isotype of serum antibodies was confirmed in four of these patients, while 
three showed discordant results regarding isotype in ELISA and Western blot, and one was negative in Western blot.

In the group of 12 patients with Waldenström disease, ELISA did not reveal serum antibodies against PNM.

Among the 109 neuropathy patients without serum M-component, ELISA revealed antibodies against PNM of one or more isotypes in $19(17 \%)$. Among these antibody-positive patients, two had GuillainBarré syndrome, one each had Lyme disease and shoulder neuritis, while the remaining 15 had polyneuropathy (table 1). Interestingly, Charcot-MarieTooth disease was diagnosed in five of these patients. The antibodies were of IgM isotypes in 13 patients, IgG in six and IgA in four. Thus, four of the patients had in their sera anti-PNM antibodies belonging to two of the three isotypes analysed. One had GuillainBarré syndrome, one vitamin $B_{12}$ deficiency and two had polyneuropathy of unknown cause. Serum from 15 of the patients being positive in ELISA were available for Western blot and seven of them showed

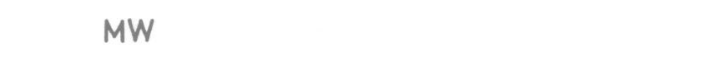

concordance with both methods.

Twenty three $(16 \%)$ of the 142 blood donors also had anti-PNM antibodies as revealed by ELISA. In 13 patients, these antibodies belonged to one isotype, in five to two different isotypes and in five to three isotypes. IgA antibodies were found most frequently, followed by antibodies of IgG and IgM isotype. Western blot carried out on 14 ELISA positive sera confirmed presence of anti-PNM antibodies, and in 10 of them there was concordance between ELISA and Western blot results.

A 25-30 kD protein was found to be the target antigen for IgM as well as for IgA anti-PNM antibodies in all three groups of patients. A $100 \mathrm{kD}$ antigen was also identified in the group of polyneuropathy patients who all lacked a serum M-component, and in the blood donors. In addition, three of the blood donors and two of the polyneuropathy patients without serum M-component displayed antibody binding to both target antigens. A survey of epitope reactivities is presented in table 2, and exemplified in fig 1 . A higher rate of confirmation of ELISA data with

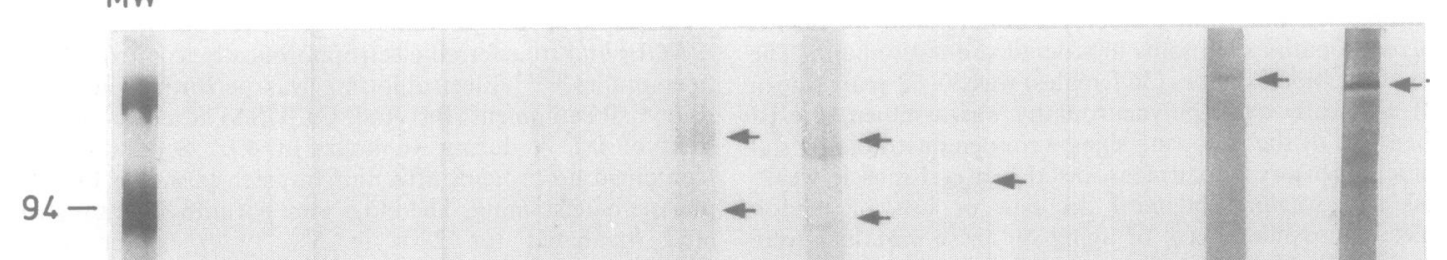


Table 2 Survey of subjects with antibody binding to target antigens found by Western blot

\begin{tabular}{|c|c|c|c|c|c|c|c|c|c|}
\hline \multirow[b]{2}{*}{ Diagnosis } & \multicolumn{3}{|c|}{ 25-30 kD protein } & \multicolumn{3}{|c|}{$100 \mathrm{kD}$ protein } & \multicolumn{3}{|c|}{ (25-30) and $100 \mathrm{kD}$ protein } \\
\hline & IgM & $\operatorname{IgA}$ & $\operatorname{Ig} G$ & $\operatorname{Ig} M$ & $\operatorname{Ig} A$ & $\operatorname{Ig} G$ & $\operatorname{Ig} M$ & $\operatorname{Ig} A$ & $\operatorname{Ig} G$ \\
\hline $\begin{array}{l}\text { Polyneuropathy with serum M-component } \\
\text { Neuropathy without serum M-component } \\
\text { Blood donors }\end{array}$ & $\begin{array}{l}6 \\
3 \\
3\end{array}$ & $\begin{array}{l}1 \\
1 \\
1\end{array}$ & $\begin{array}{l}0 \\
0 \\
0\end{array}$ & $\begin{array}{l}0 \\
2 \\
4\end{array}$ & $\begin{array}{l}\mathbf{0} \\
0 \\
\mathbf{3}\end{array}$ & $\begin{array}{l}\mathbf{0} \\
3 \\
1\end{array}$ & $\begin{array}{l}0 \\
2 \\
3\end{array}$ & $\begin{array}{l}\mathbf{0} \\
\mathbf{0} \\
\mathbf{0}\end{array}$ & $\begin{array}{l}\mathbf{0} \\
0 \\
\mathbf{0}\end{array}$ \\
\hline
\end{tabular}

Western blot findings was obtained for IgM isotype than IgA and IgG. Notably, several of the ELISA absorbance values registered among blood donors exceeded many of the values noticed among the patients with polyneuropathy and M-component. (fig 2).

\section{Discussion}

Our data show that occurrence of serum antibodies against PNM is not restricted to patients with polyneuropathy and paraproteinaemia, but can also be demonstrated in patients with polyneuropathy of different aetiology and lacking serum M-component, and in healthy controls. Quantities of antibodies as measured by ELISA, isotype of the PNM antibodies or target antigen did not clearly differ between these three groups. Therefore, any primary pathogenic role of these antibodies is doubtful. However, harmful effects of the antibodies may still occur in presence of damaged blood nerve barrier and/or inflammation within the peripheral nervous system.

A complete homology for the presence of antiPNM antibodies of different isotypes between the results with ELISA and Western blot was recorded in slightly more than half of the subjects tested. The discrepancies observed might be explained by differences in antibody binding to different or changed epitopes in the two assays, as well as possible alter-

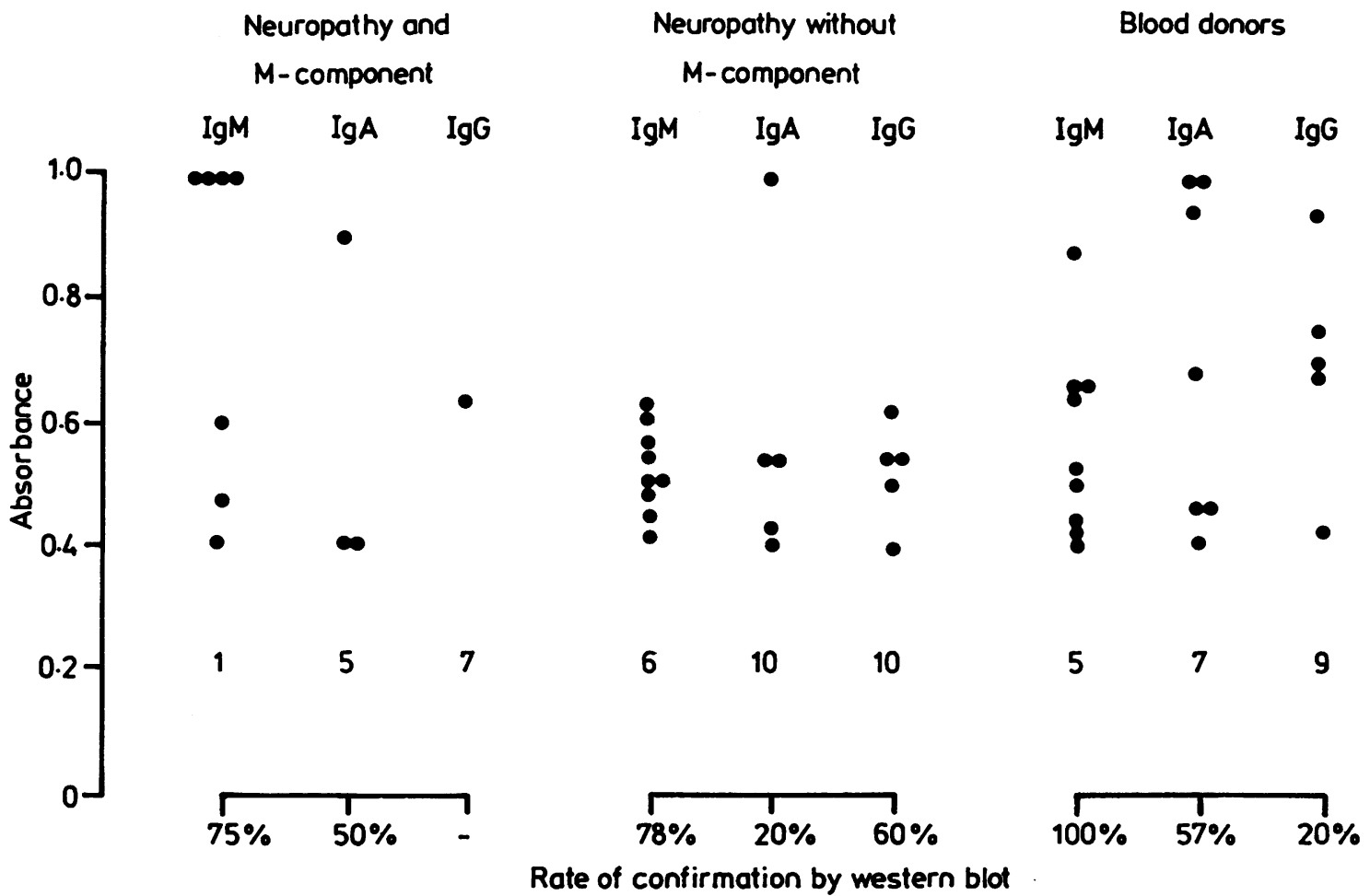

Fig 2 Survey of the material where ELISA had shown presence of antibodies against PNM and samples were available for Western blot. Numbers at absorbance 0-2 correspond to numbers of samples negative in ELISA. The rate of confirmation of ELISA positivity by the Western blot is expressed as percentages for each isotype and diagnostic group. Note the high concordance for $\mathrm{Ig} M$ isotype, and also occurrence of absorbance values among blood donors exceeding values in patients with neuropathy and serum M-component. 
ations of configuration and antigenicity of myelin constituents induced by SDS-PAGE. Our Western blot data corroborate previous findings that serum IgM M-components in patients with polyneuropathy and paraproteinaemia react with a $25-30 \mathrm{kD}$ PNM protein. ${ }^{916-18}$ Other antigens implicated in this context have been myelin-associated glycoprotein 81920 and glycolipids. ${ }^{1721}$ These two latter epitopes were not studied. Since the $25-30 \mathrm{kD}$ antigen was the target for antibodies of different isotypes found in serum from some of our neuropathy patients lacking $M$ protein and also from some of our healthy controls, it seems clear that presence of these auto-antibodies lacks specificity for polyneuropathy in paraproteinaemia.

The presently observed natural occurrence of nervous system autoantibodies is not unique for $25-30$ $\mathrm{kD}$ and $100 \mathrm{kD}$ proteins of PNM origin. Antibodies against other nervous tissue antigens have been reported in sera from healthy individuals, for example, antibodies to $200 \mathrm{kD}$ neurofilament protein ${ }^{22}$ as well as non-neural autoantigens. ${ }^{23}$

The high frequency of anti-PNM antibodies observed in our Charcot-Marie-Tooth patients is of interest. The chronic demyelination occurring in this disease might well create a secondary immune response which includes appearance of autoantibodies against myelin. Our observation of antibodies against PNM in some of our patients with Guillain-Barre syndrome is in accordance with previous demonstration of antibodies in sera from patients with this disease binding to peripheral nerve homogenates and to PNM. ${ }^{24} 25$ Furthermore, sera from patients with polyneuropathy and paraproteinaemia, as well as with Guillain-Barré syndrome, have been shown to induce demyelination when injected into peripheral nerve. ${ }^{26}$ Accordingly, antibodies against myelin have been thought to play a role in the pathogenesis of corresponding polyneuropathy.

Our data indicate that antibodies against PNM can be included in the expanding group of autoantibodies which may be a normal serum constituent with yet unidentified function. ${ }^{27}$ Neither quantitation of antiPNM antibodies, nor definition of antigenic targets by Western blot nor definition of isotype of these antibodies seems to be of any definite help in evaluating their possible relevance in pathogenesis of polyneuropathy. Currently, determination of antibodies against PNM seems to have restricted value in the laboratory evaluation in polyneuropathy. Whether assessment of antibodies against myelin subcomponents or measurement of antibody secretion on the cellular level will yield more valuable information in this context is now being examined in our laboratory.

The excellent technical assistance of Mrs Lola
Björkqvist, Mrs Monica Dufmats, and Mrs Christina Ekefeldt is gratefully acknowledged. We thank Ms Yvonne Nilsson for preparation of the manuscript.

This study was supported by grants from the Swedish Medical Research Council (projects No. 3381 and 7488), and the Swedish Society for Disabled.

\section{References}

1 Kahn SN, Riches PG, Kohn J. Paraproteinaemia in neurological diseases: incidence, association and classification of monoclonal immunoglobulins. J Clin Pathol 1980;33:617-21.

2 Kelly JJ. Peripheral neuropathies associated with monoclonal protein, a clinical review. Muscle Nerve 1985;8:139-50.

3 Julien C, Vital C, Vallat JM, et al. Chronic demyelinating neuropathy with IgM-producing lymphocytes in peripheral nerve and delayed appearance of "benign" monoclonal gammopathy. Neurology 1984;34:1387-9.

4 Nobile-Orazio E, Latov N, Haus AP, et al. Neuropathy and anti-MAG antibodies without detectable serum M-protein. Neurology 1984;34:218-21.

5 Geczy C, Raner R, Roberts I, et al. Macrophage procoagulant activity as measure of cell mediated immunity to P2 protein of peripheral nerve in the Guillain-Barré syndrome. $J$ Neuroimmunol 1985; 9:179-91.

6 Kadlubowski M, Hughes RA, Gregson NA. Experimental allergic neuritis in Lewis rat characterization of the activity of peripheral myelin and its major basic protein P2. Brain Res 1980;184:439-54.

7 Nobile-Orazio E, Vietorisz T, Messito MW, et al. AntiMAG IgM antibodies in patients with neuropathy and IgM M-protein: detection by ELISA. Neurology 1983;33:932-42.

8 Braun PE, Frail DE, Latov N. Myelin associated glycoprotein is the antigen for a monoclonal IgM in polyneuropathy. $J$ Neurochem 1982;39:1261-5.

9 O'Shanessy DJ, Ilyas AA, Dalakas MC, et al. Specificity of human IgM-monoclonal antibodies from patients with PN. J Neuroimmunol 1986;11:131-6.

10 Steck AJ, Murray M, Meir C, et al. Demyelinating neuropathy and IgM antibody to myelin associated glycoprotein. Neurology 1983;33:19-23.

11 Ernerudh J, Brodtkorb E, Olsson T, et al. Peripheral neuropathy and monoclonal IgM with antibody activity against peripheral nerve myelin effect of plasma exchange. $J$ Neuroimmunol 1986;11:171-8.

12 Laemmli UK. Cleavage of structural proteins during assembly of the head of bacteriophage T4. Nature 1971;227:680-5.

13 Towbin H, Staehelin T, Gordon J. Electrophoretic transfer of proteins from polyacrylamide gels to nitrocellulose sheets: procedure and same applications. Proc Natl Acad Sci USA 1979;76:4350-4.

14 Olsson T, Kostulas V, Link H. Improved detection of oligoclonal IgG in cerebrospinal fluid by agarose isoelectric focusing, double-antibody peroxidase and 
avidin-biotin amplification. Clin Chem 1984;30: 1246-9.

15 Cruz MH, Olsson T, Ernerudh J, et al. Immunoblot detection of oligoclonal IgG antimyelin basic protein antibodies in cerebrospinal fluid of multiple sclerosis patients. Neurology 1987;37:1515-9.

16 Nobile-Orazio E, Hays AP, Latov N, et al. Specificity of mouse and human monoclonal antibodies to myelinassociated glycoprotein. Neurology 1984;34:1336-42.

17 Chou KH, Ilyas AA, Evans JE, et al. Structure of a glycolipid reacting with monoclonal IgM in neuropathy and with HNK-1. Biochem Biophys Res Commun 1985;128:383-8.

18 O'Shanessy DJ, Willison HJ, Inuzuka T, et al. The species distribution of nervous system antigens that react with myelin-associated glycoprotein antibodies. J Neuroimmunol 1985;9:255-68.

19 Melmed C, Frail D, Duncan I, et al. Peripheral neuropathy with IgM kappa monoclonal immunoglobulin directed against myelin-associated glycoprotein. Neurology 1983;33:1397-405.

20 Latov N, Braun PE, Gross RB, et al. Plasma cell dyscrasias and peripheral neuropathy: identification of the myelin antigens that react with human paraproteins. Proc Natl Acad Sci USA 1981;78:7139-42.

21 Miyatani NM, Hiroko-Baba, Sato S, et al. Antibody to syalosyllactos-amynilpartragloboside in a patient with paraproteinaemia and polyradiculoneuropathy. $J$ Neuroimmunol 1987;14:189-96.

22 Stefanson K, Maron LS, Diepering MD, et al. Circulating autoantibodies to the 200,000 daltons protein of neurofilaments in the serum from healthy individuals. Science 1985;228:1117-9.

23 Gilbert B, Dighiero G, Avrameas S. Naturally occurring antibodies against nine common antigens in human serum. J Immunol 1982;128:2779-86.

24 Melnick SC. Thirty-eight cases of Guillain-Barré syndrome: an immunological study. $\mathrm{Br}$ Med J 1963;1: 368-73.

25 Cook S, Dowling PC. The role of autoantibodies and immunocomplexes in the pathogenesis of GuillainBarré syndrome. Ann Neurol 1981;9 (suppl):70-9.

26 Feasby TE, Hahn AF, Gilbert JJ. Passive transfer of demyelinating activity in Guillain-Barré polyneuropathy. Neurology 1980;30:363.

27 Avrameas S, Guilbert B, Dighiro B. Natural antibodies against tubulin actin myoglobin, thyroglobulin, fetuin and transferin are present in normal human sera and monoclonal immunoglobulins from multiple myelome and Waldenström macroglobulinemia may express similar antibody specificities. Ann Immunol 1981;132C:103-13. 